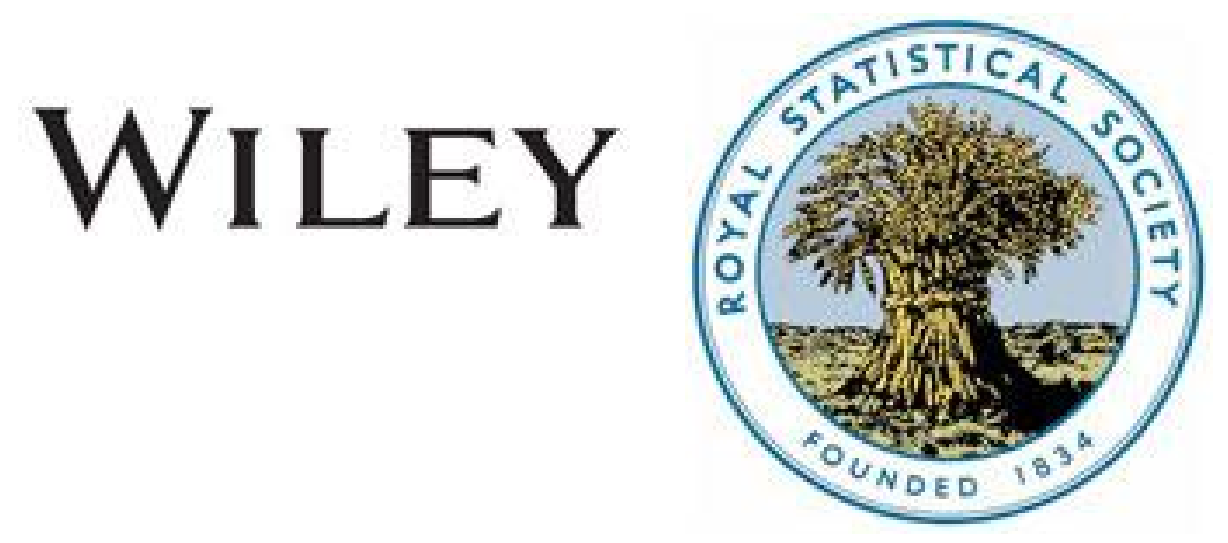

Ocean Highways: Their Bearing on the Food and Wages of Great Britian Author(s): George Hamilton

Source: Journal of the Royal Statistical Society, Vol. 57, No. 1 (Mar., 1894), pp. 104-135 Published by: Wiley for the Royal Statistical Society

Stable URL: http://www.jstor.org/stable/2979419

Accessed: 27-06-2016 10:28 UTC

Your use of the JSTOR archive indicates your acceptance of the Terms \& Conditions of Use, available at

http://about.jstor.org/terms

JSTOR is a not-for-profit service that helps scholars, researchers, and students discover, use, and build upon a wide range of content in a trusted digital archive. We use information technology and tools to increase productivity and facilitate new forms of scholarship. For more information about JSTOR, please contact support@jstor.org.

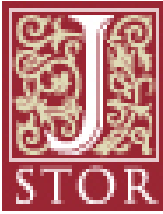

Wiley, Royal Statistical Society are collaborating with JSTOR to digitize, preserve and extend access to Journal of the Royal Statistical Society 


\section{Ocean Highwats: their Bearing on the Food and Wages of Great}

\section{Britain. By The Right Hon. Lord George Hamilton, M.P.}

[Read before the Royal Statistical Society, 20th Felruary, 1894.

The President, Charles Booth, Esq., in the Chair.]

IT is with some trepidation that I undertake to read a paper on the above subject before this Society; but the opinions therein stated, and the propositions sought to be established, are the result of long personal acquaintance with and study of a question which, beyond all others, affects the material wellbeing of the country, and which, so far as I know, has not been yet examined or pronounced upon by statisticians except in a somewhat perfunctory and casual manner.

I have therefore endeavoured to put the successive stages of reasoning, by which $I$ arrive at certain conclusions, in such a statistical form as will enable the practised controversialists in this Society to rapidly test their soundness or fallacy.

Many of the most notable papers read in recent years before this body have demonstrated the rapid augmentation of wealth which, decade by decade, this country has and is accumulating under a policy of practically free imports; and the labours and investigations of some of the ablest and best known statisticians have been devoted with great success to tracing the distribution of this increase of substance with a view of ascertaining how far all sections of the community have benefited by it. The result of their labours has been to show that the distribution and dispersion of this increase of wealth has been wide and general, so much so that notwithstanding the great growth of the population as shown by the decennial censuses, the material position of all classes has continuously improved, so far as wellbeing can be tested by accurate estimates of income and consumption.

A great and marked success in these respects has attended our past policy of freeing imports from hostile imposts or obstructive tariffs. But the continuous success of a policy of free imports into an island ( $\mathrm{I}$ use these words advisedly in place of those generally in vogue, "free trade," for situated as Great Britain is, it is her importing powers which dominate her exporting capacity) largely depends upon the free control and uninterrupted use of the ocean highways leading to that island. England has had that great advantage for a continuous and uninterrupted period of 
nearly ninety years, for from the date of the battle of Trafalgar up to now she has been undisputed mistress of the area which these trade routes and highways traverse. Mr. Glover, in March, 1892, read a paper before the Society in which he showed for the later half of this period of ninety years, viz., from 1850 to 1890, the use this country had made of the advantages of long and unbroken free ocean transport. Taking decade by decade he showed that the total entries and clearances at the ports of the United Kingdom had grown with unexampled rapidity.

In 1850 the total entries and clearances were under 40 million tons; in 1860 they were under 59 million tons; in the next decade, 1870 , they had reached 73 million tons; in the next ten years, 1880 , they had grown to 133 million tons; and finally in 1890 they had arrived at the high figure of 164 million tons.

Thus, within a period of forty years the entries and clearances by our marine transport have more than quadrupled themselves. But these figures contain the tonnage entered and cleared coastwise, which relate more to the home than foreign trade. The table below gives the tonnage over this period appertaining to both classes of trade:-

[000's onitted.]

\begin{tabular}{|c|c|c|c|}
\hline & $\begin{array}{c}\text { Total } \\
\text { Entries and Clearances. }\end{array}$ & Coastwise. & Fureign Trade only. \\
\hline 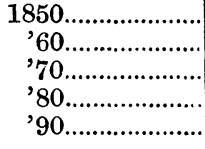 & $\begin{array}{r}39,634, \\
58,707, \\
73,198, \\
133,250, \\
164,340,\end{array}$ & $\begin{array}{l}25,129 \\
34,017 \\
36,558 \\
74,514 \\
90,056\end{array}$ & $\begin{array}{l}14,505, \\
24,689, \\
36,640, \\
58,736, \\
74,283,\end{array}$ \\
\hline
\end{tabular}

It will thus be seen that the increase in the foreign trade is relatively greater than in the coast trade, and that whereas the total entries and clearances have quadrupled themselves in this period, the foreign trade entries and clearances have risen from I $4 \frac{1}{2}$ millions to 74 millions, and quintupled themselves.

During this period the population has risen from 27,721,056 in 1850 , to $38,101,975$ in 1890 .

I have had some difficulty in obtaining accurate data upon which to base an estimate of the income of the country at the beginning and end of this period; but Mr. Giffen, in his "Essays " in Finance," 2nd series, p. 433, accepts, in the following words, Professor Leone Levi's calculations for a certain portion of this period, viz., from 1867-84, as regards the relative earnings of the working classes, both in the aggregate and individually :-

"In the seventeen years 1867-84, Professor Levi finds that " the aggregate earnings of the working classes have risen from 
" 418 million $£$ to 520 million $£$, or nearly 25 per cent., the " increase of the numbers being only II per cent.; and the " average increase per head is from $38 l$. to $42 l$. 14s.- or rather " more than i I per ceut."

We may therefore safely accept this statement, although it only covers a portion of the period with which I am dealing, and assume that for the remainder of the period the earnings per head of the working classes were on the rise and not on the fall.

As regards the rise and fall of the price of necessaries, the "Agricultural Returns for Great Britain for 1892" (published by the Board of Agriculture, C-6743), give us most valuable information, for on p. 23 is shown the price of wheat, barley, and oats for the last twenty years :-

\begin{tabular}{|c|c|c|c|c|}
\hline Year. & Wheat, per Quarter. & Barley, per Quarter. & Oats, $p$ & Quarter. \\
\hline 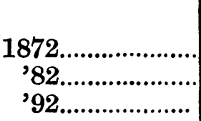 & $\begin{array}{ll}\text { s. } & d . \\
57 & - \\
45 & 1 \\
30 & 3\end{array}$ & $\begin{array}{ll}s . & d . \\
37 & 5 \\
31 & 2 \\
26 & 2\end{array}$ & $\begin{array}{l}s . \\
23 \\
21 \\
19\end{array}$ & $\begin{array}{l}d . \\
2 \\
10 \\
10\end{array}$ \\
\hline
\end{tabular}

and for meat during the same time:-

\begin{tabular}{|c|c|c|c|}
\hline Year. & Beef. & Mutton. & Pork. \\
\hline $\begin{array}{r}1872 \ldots . . . . \\
' 82 \ldots . . . . . \\
' 92 \ldots . . .\end{array}$ & 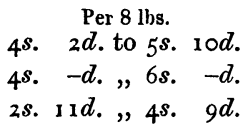 & $\begin{array}{l}\text { Per 8lbs. } \\
\text { 4s. 10d. to 6s. } 8 d . \\
\text { 5s. 4d. , 7s. } 2 d . \\
\text { 3s. 7d. , } 5 s .7 d .\end{array}$ & 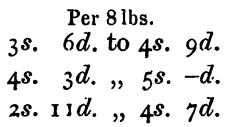 \\
\hline
\end{tabular}

and the fall in price, combined with the rise in wage, has resulted in the following gratifying increase of consumption per head of the population of food imported from abroad:-

\begin{tabular}{|c|c|c|c|c|c|c|c|}
\hline Periods. & $\begin{array}{l}\text { Wheat } \\
\text { in } \\
\text { Grain. }\end{array}$ & Flour. & $\begin{array}{l}\text { Pota- } \\
\text { toes. }\end{array}$ & $\begin{array}{l}\text { Fresh } \\
\text { Beef, } \\
\text { Mutton } \\
\text { and } \\
\text { Pork. }\end{array}$ & $\begin{array}{l}\text { Bacon } \\
\text { and } \\
\text { Hams. }\end{array}$ & $\begin{array}{c}\text { Butter } \\
\text { and } \\
\text { Margarine } \\
\text { and } \\
\text { Cheese. }\end{array}$ & Eggs. \\
\hline $\begin{array}{cr}\text { Arge. of } 5 \text { years } 1871-75 \\
, " 76-80 \\
" & ' 81-85 \\
", & ' 86-90 \\
\text { Single year } 1891 & \ldots . . . . . . . .\end{array}$ & $\begin{array}{l}\text { lb. } \\
152 \\
174 \\
186 \\
170 \\
196\end{array}$ & $\begin{array}{l}\text { lb. } \\
19 \\
28 \\
45 \\
48 \\
49\end{array}$ & $\begin{array}{r}\text { lb. } \\
16 \\
28 \\
11 \\
7 \\
9\end{array}$ & $\begin{array}{r}\text { lb. } \\
0 \cdot 2 \\
1 \cdot 7 \\
3 \cdot 5 \\
7 \cdot 0 \\
11 \cdot 0\end{array}$ & $\begin{array}{l}\text { lb. } \\
7.8 \\
13.5 \\
11.8 \\
12.9 \\
14^{\circ} \cdot 0\end{array}$ & $\begin{array}{r}\mathrm{lb} . \\
9.5 \\
11.9 \\
12.9 \\
14.5 \\
16.0\end{array}$ & $\begin{array}{l}\text { No. } \\
19 \\
22 \\
26 \\
31 \\
34\end{array}$ \\
\hline
\end{tabular}

It will be observed by a study of this table that the consumption of the main necessaries of life contained in it have risen greatly, with the single exception of potatoes, and the fall in the import of this vegetable per head is not unsatisfactory, for it does not 
indicate a reduction in the general consumption of vegetables throughout the United Kingdom, but a diminution of the class who entirely depended upon that vegetable for their sustenance, and the substitution generally of more nutritious food in its place.

I speak subject to correction, but I believe that I am accurate in saying that such an increase of population in so circumscribed and long settled a country, accompanied by such a rise in wages and such a fall in the price of the main necessaries of life, is without precedent, or at any rate without authentic statistical record.

Cause and effect are here placed in close relation. It is because access to the highways of the sea have for so long a time been free and undisputed, that Great Britain has been able to so utilise her insular geographical position, and thus rapidly develop the other many advantages which the possession of exceptional mineral wealth gives her. This combination has enabled her to reverse the social and economic phenomena of the past, and with an increasing population, pressing upon the means of subsistence, to lower the cost of the necessaries of life, and yet increase the wage remuneration of her industrial classes.

The feat is remarkable. This little island, situated at one end of the smallest continent of the world, has so developed her mercantile marine and ocean carrying transport, that she holds under her flag alone 72 per cent. of the total ocean steam going tonnage (see Glover, March, 1892, Table XV) of the whole world. Through the instrumentality of her navy and this vast merchant fleet, she has not only established great colonies and dependencies beyond the sea, but she has absorbed and retained the larger proportion of the trade of these expanding communities, and she has in addition laid the whole world under contribution to administer to the wants and food requirements of her increasing population.

These great achievements are worth recording and eulogising; but we must never forget that remarkable as they are, conducive as they have been to the prosperity and wellbeing of the community, they carry within themselves the germ of an ever present and ever increasing danger. Every year we are becoming more and more dependent upon others for the means of daily subsistence, not only as regards the supply of food, but also of that raw material upon which the great mass of our home industries depend.

Free and independent are the two epithets by which Englishmen love to describe the characteristics of themselves, their country, and their customs. Free we may be, but independent we certainly are not. We are less self contained, less self supporting, and more dependent upon others than any great nation of the past or present, and our actual and relative dependence upon others must increase year by year and decade by decade, for we 
cannot go back or attempt to reverse the policy of free imports, the results and benefits of which have alone enabled a dense population of nearly $40,000,000$ to be packed into these islands under conditions of comfort and improvement.

It is not a question of food supplies only. Foreign supplies and foreign raw material are now the foundation and mainspring of our huge internal fabric of industrial employment; and as these industries develop with the growth of population, they cannot become less dependent upon supplies brought to them across the sea.

For ninety years we have had command and control of the sea and its waterways ; and ninety years, equal to three generations, is a long period in the life of any nation. Englishmen have thus got into the habit of regarding the free use of the sea in all times and under all conditions as an inalienable right, a heritage that is protected by some irrevocable law of trespass, and the likelihood of any interference with or loss of this power is to many minds so beyond the horizon of the possible, that it is dismissed as an unnatural contingency no more likely to occur than the destruction of these islands by earthquake.

Immunity in the past is no guarantee for the future, unless the conditions of the past and future are alike and unchangeable. That the conditions under which we gained and have retained the control of the sea have changed and are changing, is but too selfevident to all statisticians who study and digest the past and present expenditure upon the navies of the world. It therefore falls well within the province of the practical statistician to attempt in some degree to forecast and calculate how far disturbance with sea routes now open would affect the food supplies of the country, and also what proportion of the industrial population are engaged in occupations wholly or in part dependent upon imports and raw material, and how far a partial stoppage of such supplies would affect their wage earning power.

The subject to be examined divides itself into three:-

1st. The marine carrying power at present employed in the export and import trade of Great Britain, classifying the tonnage of the vessels so engaged according to nationality, dividing this classification again into steam ships and sailing ships.

2 nd. The amount of articles of food now imported into this country by such tonnage, and what proportion of the total food supplies of the country such imports constitute.

3rd. To what extent the staple trades and industries of the country are affected by foreign imports, or dependent upon them for their maintenance.

The two first branches of the subject have in some shape or other been so frequently the subjects of discussion in this Society, 
that they offer no special features of novelty, but the third is one of absorbing interest from an industrial, I might go further and say from a national, standpoint. So far as I know it has not been made the subject of close statistical investigation. My paper to-night makes no pretence of doing more than initiating an inquiry into and examination of this complicated and sinuous question in the hope that hereafter abler and more practised hands will follow up, test, and amplify the limited conclusions at which I have been able to arrive.

In dealing with the statistics (1) of tonnage, (2) imports of food, and (3) imports of raw material, I have been unable to adopt a synchronous year for all three sets of figures, but as the tendency of the figures $I$ use is very unmistakeable, and their direction very clear, the argument $I$ base apon them will in no sense be affected by the year of illustration not being identical in every case. For the tonnage statistics I have taken the year 1890, as it was with the figures of that year that Mr. Glover's paper of March, 1892, dealt, and he has so closely dissected and so ably pointed out the meaning of the returns he used, that I am glad to avail myself of his experience and unquestionable authority in utilising the figures again.

\section{Tonnage Statistics.}

For the year 1890 the total tonnage entered and cleared in the foreign trade only at ports in the United Kingdom was 74,283,000, but the total amount similarly entered and cleared with cargoes only was $62,83^{6}, 000$, and its distribution amongst the various nationalities was as follows (see Table IX, Glover, "Tonnage " Statistics," March, 1892) :-

\begin{tabular}{|c|c|c|c|}
\hline Nationality. & Steam. & Sailing. & Total. \\
\hline British ............................... & $42,127,266$ & $4,278,984$ & $46,406,250$ \\
\hline 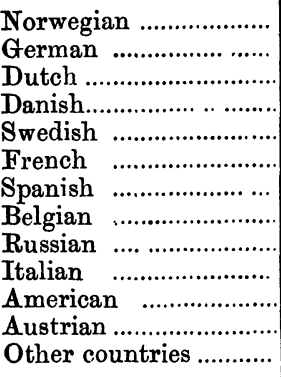 & $\begin{array}{r}917,105 \\
2,523,635 \\
1,645,283 \\
1,029,044 \\
826,692 \\
984,550 \\
1,114,086 \\
692,994 \\
145,218 \\
67,319 \\
108,558 \\
36,833 \\
237,177\end{array}$ & $\begin{array}{r}2,875,634 \\
831,119 \\
123,621 \\
456,572 \\
621,867 \\
286,631 \\
40,204 \\
3,127 \\
311,403 \\
297,002 \\
164,177 \\
64,081 \\
25,893\end{array}$ & $\begin{array}{r}3,792,739 \\
3,354,754 \\
1,768,904 \\
1,485,616 \\
1,448,559 \\
1,271,181 \\
1,154,290 \\
696,121 \\
456,621 \\
364,321 \\
272,735 \\
100,914 \\
263,070\end{array}$ \\
\hline Total foreign & $10,328,494$ & $6,101.331$ & $16,429,825$ \\
\hline $\left.\begin{array}{c}\text { Total British and } \\
\text { Foreign................... }\end{array}\right\}$ & $52,455,760$ & $10,380,315$ & $62,836,075$ \\
\hline
\end{tabular}


It will thus be seen that of the tonnage cleared, $4,278,984$ tons British and 6,10I,33 I tons foreign was sailing, making an aggregate of $10,380,315$ sailing tonnage out of a total of $62,836,075$; in other words, upwards of 16 per cent. of the sea carriage supplying us with foreign food and material is still propelled by sail power.

In speaking of our mercantile fleet, scattered all over the universe, and coming to and going from every port of consideration in the world, it must always be remembered that the proportion of it which trades between the United Kingdom and a foreign port has always to start from and return to a given centre, and that this centre is Great Britain.

Any statistician who has studied trade routes knows well that, where the current of trade is denoted by trade routes, from all parts of the world are issuing small streams of merchant vessels gradually converging closer and closer, until finally the great bulk of the carrying trade becomes a series of thickening columns which converge and meet at the entrance to the Irish and British Channels. Molestation to commerce is more apt to occur when the current of it is continuous and the course certain than where sea room is plentiful, and ships few; and this is especially the case with sailing vessels. I think we can all of us, without a great strain of imagination, depict to ourselves circumstances under which the risk to sailing vessels attempting to trade with Great Britain would be such that they would not attempt it, and be laid up. Sixteen per cent. of the sea transport now supplying our wants would at once disappear. But this reduction of sea carriage would not be confined to sailing vessels only; the steam transport would also be affected, but to what extent it is not very easy to estimate.

The diminution which would occur in the steam tonnage trading between Great Britain and foreign countries, in the event of Great Britain being a belligerent, must largely depend upon the naval strength of the enemy, or combination of enemies, with which she was fighting. But we have certain data as to the speed of much of the tonnage so engaged, and by analysing these figures, and looking to the growth in recent years of the shipping engaged in this transport, we can form some kind of an idea of what the limits of contraction would be. In the returns from the "Warships of the World," 1893, are included certain statistics as to the steam tonnage and speed of merchant vessels of different nationalities, and those belonging to Great Britain and their colonies are returned as being 7,075 in number, with a gross tonnage of 9,544,394 tons, those of the rest of the world being 5,583 , with a gross tonnage of $5,720,024$, and the following 
table gives the number of British vessels of twelve knots and upwards :-

British Shipping. Numbers and Gross Tonnage of British Merchant Steamers of a Speed of Twelve Knots an Hour and upwards.

(Compiled from Lloyd's "Warships of the World," 1893.)

\begin{tabular}{|c|c|c|}
\hline Speed. & Number of Steamers. & Gross Tonnage. \\
\hline 19 knots and above & $\begin{array}{r}19 \\
4 \\
21 \\
14 \\
24 \\
12 \\
26 \\
13 \\
51 \\
24 \\
103 \\
45 \\
145 \\
80 \\
188\end{array}$ & $\begin{array}{r}77,303 \\
6,874 \\
46,822 \\
66,489 \\
40,100 \\
27,210 \\
66,062 \\
32,222 \\
111,188 \\
59,028 \\
269,289 \\
116,082 \\
356,881 \\
209,105 \\
450,820\end{array}$ \\
\hline Total & 769 & $1,935,475$ \\
\hline
\end{tabular}

Thus only 20 per cent. of our total tonnage has a speed of twelve knots and upwards, and of the remaining 80 per cent. a very large proportion must be of low speed; and the same estimate applies to foreign steamships. According to Mr. Glover's paper, the amount of steam tonnage of all nationalities entered and cleared in $\mathbf{1 8 9 0}$ in the British ports in foreign trade alone was $52,455,760$, having risen from 32,121,056, the amount cleared in 1880 , being an increase of $20,334,704$ in a decade. Now, assuming that we were to retain 50 per cent. of this vast increase in war time, and that our clearances were not affected to a greater extent by any combination against us, we have a reduction of about $10,000,000$ tons on a total of $62,836,000$ tons, being equal to a fall of 16 per cent. This, together with the fall of $16 \frac{1}{2}$ per cent. in the sailing clearances, makes a total reduction of over $32 \frac{1}{2}$ per cent., or nearly a third of our total clearances. I make this the estimate of reduction which I shall apply to the figures in the remaining part of the paper, as being not unlikely to occur at the beginning of a war if the command over the sea was intermittent and imperfect.

\section{Imported Supplies of Food.}

The development of the supplies of food from abroad during the last twenty years has been so steady and continuous, that it is 
not generally realised how great a revolution has in that period been effected by the greatly extended area from which our food is drawn, and the annually increasing proportion which foreign imported food bears to home prodnce.

Dividing the main necessaries which are obtained from foreign and home sources of life into three heads-1, meat; 2, butter, margarine, cheese, and eggs; and 3, flour and other forms of corn and meal-the following heads give the actual increase in value since 1871 of the imports of these items of food :-

\begin{tabular}{|c|c|c|c|}
\hline \multirow{5}{*}{ 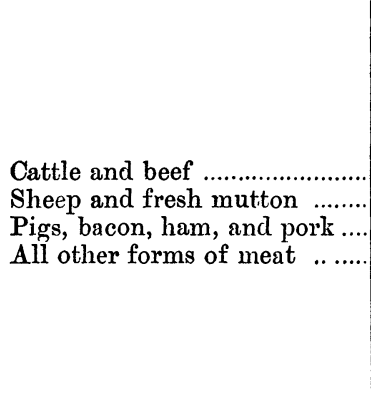 } & \multicolumn{3}{|c|}{ Import of Meat, \&c. } \\
\hline & 1871. & 1881. & 1891. \\
\hline & $\begin{array}{r}£ \\
4,218,000 \\
1,790,000 \\
3,710, r 00 \\
770,000\end{array}$ & $\begin{array}{r}£ \\
8,915,000 \\
2,192,000 \\
\text { II }, 493,000 \\
2,154,000\end{array}$ & $\begin{array}{r}\mathscr{E} \\
14,270,000 \\
4,082,000 \\
10,042,000 \\
713,000\end{array}$ \\
\hline & $10,488,000$ & $24,754,000$ & $29,107,000$ \\
\hline & \multicolumn{3}{|c|}{ Import of Butter, \&c. } \\
\hline \multirow[t]{2}{*}{ 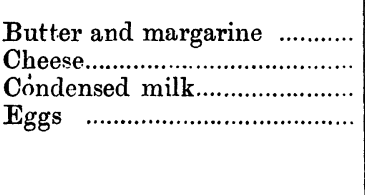 } & $\begin{array}{c}6,939,000 \\
3,341,000 \\
- \\
1,264,000\end{array}$ & $\begin{array}{r}10,866,000 \\
5,245,000 \\
2,322,000\end{array}$ & $\begin{array}{r}15,149,000 \\
4,813,000 \\
900,000 \\
3,506,000\end{array}$ \\
\hline & $11,544,000$ & $18,433,000$ & $24,368,000$ \\
\hline \multirow{3}{*}{ 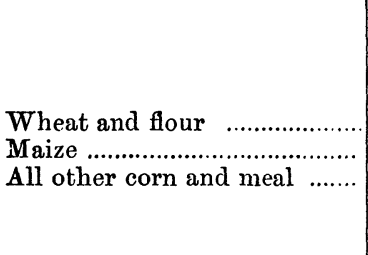 } & \multicolumn{3}{|c|}{ Import of Wheat, \&c. } \\
\hline & $\begin{array}{r}26,817,000 \\
6,469,000 \\
9,405,000\end{array}$ & $\begin{array}{r}40,737,000 \\
10,408,000 \\
9,7 \times 1,000\end{array}$ & $\begin{array}{r}39.633,000 \\
8,412,000 \\
13,977,000\end{array}$ \\
\hline & $42,691,000$ & $60,85^{5,000}$ & $62,022,000$ \\
\hline 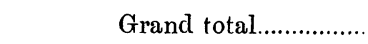 & $64,723,000$ & $104,043,000$ & $115,497,000$ \\
\hline
\end{tabular}

(Note.--These figures and the following tables are all taken from the tables in "General Report," pp. xviii-xxviii, of “Agricultural Returns, 1892.")

These statistics show a rise in the value of these articles of imported food in twenty years of from 64,7 I $3,000 l$. to I I $5,487,000 l$. The constant fall in the price of the articles makes any money value, taken on the prices current in the year, a delusive test as to the real increase of the amount of food thus imported.

Taking the quantities imported, and estimating them for each of the years on that basis, we get the following results :- 


\begin{tabular}{|c|c|c|c|c|}
\hline & 1871. & 1881. & 1891. & $\begin{array}{c}\text { Percentage } \\
\text { of } \\
\text { Increase between } \\
\text { 1871-91. }\end{array}$ \\
\hline Live animals, representing .... & $\begin{array}{l}\text { 'l'ons. } \\
90,500\end{array}$ & $\begin{array}{l}\text { Tons. } \\
\text { I I } 7,500\end{array}$ & $\begin{array}{l}\text { Tons. } \\
171,500\end{array}$ & $89^{\circ} 5$ \\
\hline Dead meat & 99,500 & 341,600 & 499,500 & $3920^{\circ}$ \\
\hline Butter, margarine, and cheese & 127,500 & 194,500 & 270,500 & $112 \cdot 1$ \\
\hline 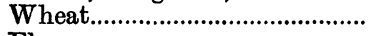 & $1,969,500$ & $2,857,500$ & $3,315,500$ & $68 \cdot 3$ \\
\hline 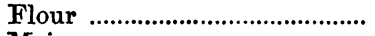 & 199,000 & 568,000 & 836,000 & $320^{\circ} 1$ \\
\hline 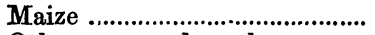 & 841,000 & $1,674,000$ & $1,341,000$ & $59^{\circ} 5$ \\
\hline Other corn and meal............... & $1,188,000$ & $1,232,500$ & $2,072,000$ & 744 \\
\hline
\end{tabular}

In the same report the Board of Agriculture affords data for estimating the changes in the home production of food in the United Kingdom, by giving the areas under cultivation and grass and the numbers of cattle and sheep.

\begin{tabular}{|c|c|c|c|c|}
\hline & 1872. & 1882. & 1892. & $\begin{array}{c}\text { Percentage } \\
\text { of Increase or } \\
\text { Decrease between } \\
1872-92 .\end{array}$ \\
\hline Cultivated area.... acres & $46,869,000$ & $47,655,000$ & $47,978,000$ & $+2 \cdot 3$ \\
\hline Corn crops & $11,698,000$ & I0,620,000 & $9,329,000$ & $-20^{\circ} 2$ \\
\hline Wheat crops & $3,84,0,000$ & $3,164,000$ & $2,299,000$ & $-40^{\circ} 1$ \\
\hline Permanent grass & $22,838,000$ & $24,963,000$ & $27,533,000$ & +20.5 \\
\hline Cattle ............... No. & $9,719,000$ & $9,832,000$ & $11,519,000$ & $+18 \cdot 5$ \\
\hline Sheep................... , , & $32,247,000$ & $27,448,000$ & $33,643,000$ & +43 \\
\hline
\end{tabular}

(It will be observed that the years taken for estimating food imports are 1871, 1881, and 1891; for estimating home production, 1872, 1882, 1892.)

The population of the United Kingdom was-

\begin{tabular}{cc|c|c|c|c}
\hline & 1871. & 1881. & 1891. & $\begin{array}{c}\text { Percentage } \\
\text { of } \\
\text { Increase between } \\
1871-91 .\end{array}$ \\
\hline Population & .... No. & $31,556,000$ & $35,208,000$ & $38,109,000$ & $20 \% 7$ \\
\hline
\end{tabular}

Taking the last three tables, viz., (1), that referring to the imports in bulk of these classes of foreign food; (2), to the home production of the same food; (3), to the growth of the population, we arrive at these conclusions-that foreign imported food produce has increased enormously, about 88 per cent.; that the home production of food has been practically stationary; and that the growth of the population during the same period has been at the rate of $20^{\circ} 7$ per cent.

The ratio of increase of foreign food, as shown by these tables, has therefore been much in excess of the ratio of increase of the VOL. LVII. PART I. 
population it supplied, and it consequently follows that at the present rates of consumption a much larger proportion of the whole population are now dependent upon foreign food than was the case twenty years back. Side by side with this change, due to external influences, internally a movement in population is taking place which adds to our dependence on foreign supplies. Although the population of Great Britain and Ireland has in the aggregate increased largely since 1851, the increase has been entirely confined to Great Britain, the Irish population having receded from $6,55^{2}, 385$ in 1851 to $4,704,750$ in 1891. But in Ireland the food supplies of the population are, to a much larger degree than in Great Britain, derived from home produce, and thus we have that part of the kingdom which is most self-supporting, so far as home-grown produce is concerned, decreasing in population, whilst those parts which are most dependent upon external food supplies increasing in population.

I have, however, hitherto only considered these articles of imported food which compete with home produce, but there are other articles, such as tea, coffee, sugar, and tobacco, which may fairly be termed necessaries of life, but the whole supply of which comes from abroad. The importation of these articles has increased, as shown in the following table:-

Imports of Tea, Coffee, Sugar, Tobacco, 1881 and 1891. Home Consumption.

[000's omitted.]

\begin{tabular}{|c|c|c|c|c|}
\hline & Tea. & Coffee. & Sugar. & Tobacco. \\
\hline $\begin{array}{r}1881 \\
91\end{array}$ & $\begin{array}{c}\text { lbs. } \\
\text { 160,226, } \\
202,456\end{array}$ & $\begin{array}{c}\text { Ibs. } \\
31,208, \\
28,622,\end{array}$ & $\begin{array}{c}\text { cwts. } \\
20,016, \\
27,407\end{array}$ & $\begin{array}{c}\text { lbs. } \\
49,330, \\
60,930\end{array}$ \\
\hline
\end{tabular}

What ratio foreign imported food bears to home produce formed part of a very interesting paper read by Mr. Stephen Bourne on the 30th November, 1892, before the Manchester Statistical Society, in which he, from tables of comparison between the years 1876 and 1891, arrived at the following conclusions: that out of 33 millions of inhabitants in 1876, 18 might be deemed to be provided from home sources, and 15 from foreign supplies; but that in 1891, out of $3^{8}$ millions of inhabitants, $16 \frac{1}{2}$ depended on home and $21 \frac{1}{2}$ on foreign supplies, or in other words that in 189155 per cent. of the food at present consumed in this country came from abroad. On that estimate every inhabitant in these islands is dependent for his food for one hundred and eighty-nine days in the year upon foreign imports, and if these imports suddenly ceased he would be foodless for over six months in the year. 
Foreign food supplies have during the last twenty years gradually obtained this preponderance because, as preceding tables have shown, home grown food has almost reached its full limits of remunerative production, and the increasing powers of consumption of a growing population had to be almost entirely met by extraneous supplies. This process must continue, and if its development during the next twenty years is as rapid as it has been in the past, in little more than twenty years hence home produce will have receded from being less than a half of the total supply of food to less than a fourth.

Whatever danger, therefore, a temporary stoppage or dislocation in the transport of our system of sea borne food might now produce, will be aggravated as time rolls on.

I have assumed that about one-third of that transport might be summarily curtailed or arrested, and if one-third of a food supply which feeds every individual in the country for one hundred and eighty-nine days be stopped, the whole population would be for sixty-three days foodless.

If such a catastrophe were to oscur, it would be beyond the power of any statistician to in any way gauge or estimate the amount of misery, suffering, and destitution which such a want of daily sustenance would entail.

A temporary stoppage of ocean highways would not only curtail the automatic supplies of food upon which this country relies, but a large and corresponding diminution must also occur in the carriage of the raw materials and foreign supplies which feed our industries and great trades.

A sudden rise in the price of the necessaries of life is, to a dense population, a terrible hardship; but if a great rise in the price of the articles to be purchased is associated with a corresponding fall in the purchasing power of the buyer, the hardship rapidly assumes the form of a wide-spread and immediate famine. Simultaneity in a wholesale scarcity of food, and a general lack of employment is, however, the certain result of our increasing dependence upon foreign supplies for the sustenance of our population and for the maintenance of their industries, and the extent to which the wage-earning power of our industrial classes depends upon the communication by sea remaining undisturbed, will now be statistically examined.

\section{Imported Supplies of Raw Material other than "Food, and the Dependence of the Industries of the Country thereon.}

This part of the inquiry necessitates a much closer investigation than the preceding portions of my paper if the immediate, inter- 
mediate, and final effects of vast imports of raw material are to be traced right throughout the windings and intricacies of our complex industrial system. I can only liken the work of trying to follow out such statistics to an effort to catch diving ducks, the nearer you get to them the more certain they are not only to disappear, but also to reappear in quarters where you least expect them.

Though I am conscious that in this part of the subject my work is crude and unfinished, still the meaning of the figures which I propose to here use, is as clear and unmistakable as those I have disposed of. They admit of but one interpretation, the increasing dependence of our industries upon foreign supplies. Such being therefore the statistical drift of the tables I am about to employ, I have been most anxious to understate rather than overstate the case I am presenting. What effect the sudden stoppage of material from abroad would have on the industries for whose wants it was required, is in almost every case regulated by the nature of the individual industry itself. In some instances the foreign material is required for mixing and blending with the native, as in the case with imported iron ore and wool, and a sudden stoppage of one ingredient essential to the manufacture of the whole commodity, would damage and disorganise the industry to an extent much beyond the mathematical proportion which the imported material bears to the whole material used by that industry. In other trades, such as those connected with wood and leather, the bulk of the raw material imported is very similar in quality and substance to the raw material produced from home sources, and in these cases the disturbance due to their contraction and stoppage might be only proportional to the ratio they bear to the total material consumed by the trade affected. I have assumed throughout that the dislocation and contraction of employment from decrease of imported material in all industries and trades, will be only proportional, though it must be manifest that in most cases this is an underestimate.

The figures which I propose to use are the Board of Trade returns for 1892. I have selected that year for two reasons : first, because it is an average year, being one between a period of expansion and a period of depression. Taking the ten years preceding, I find that, as regards its imports and exports, the year 1892 represents the average of that decade, being below the volume of five years and above that of the remaining five. It is also the latest year the figures of which have been thoroughly classified and analysed.

The ten trades which I propose to select by way of test and illustration are :- 
1. The steel and iron trades.

2. Wool and worsted.

3. Cotton.

4. Flax.

5. Gutta percha and caoutchouc.
6. Hides and leather.

7. Wood and timber.

8. Bristles and brush making.

9. Silk.

10. Hemp and jute.

These industries divide themselves into three classes: (1.) Those which are indigenous, and established in consequence of the proximity of raw material, such as steel, wool, flax, leather, wood. (2.) Those which have been artificially created from superiority of means of manufacture and transport, and entirely dependent on foreign supplies, such as silk, cotton, and jute. (3.) Those inseparable from the wants of a civilised community, such as brushmaking, and the manufacture of gutta percha goods.

The headquarters of these industries are scattered all over the kingdom. Some are inland, some on the seaboard, some in Ireland, some in Scotland, and they differ much in the nature of the employment they give, in the class of workmen they engage, in the amount of the wage they distribute. Outwardly there is little or no connection between them, but I will show that one and all have a common interest in what is the origin of their prosperity and existence: free access to the ocean highways.

\section{Iron and Steel Trade.}

For the year 1892 the total home production of iron ore (according to the "Mineral Statistics of the United Kingdom " for 1892," p. 42) was 1 1 312,675 tons, and the imported supply $3,780,505$ tons. Imported ore therefore stands to total production at the rate of $\mathrm{I}$ to 4 , or 25 per cent. of the total amount raised. The number of persons engaged in those industries directly dependent on steel and iron, according to the census returns of 1891 (see Table A), is $938,44^{8}$. The proportional number of persons whose employment depends on imported supplies of foreign ore is $234,6 \mathrm{r} 2$.

This industry has in recent years greatly changed its character, -owing to the cheap and rapid processes of converting iron into steel. Foreign ore is required in most of the processes to be blended and mixed with the native ore.

\section{Wool and Worsted Imports, Alpaca, Goats' Hair, and Yarn.}

The home production, in 1892, of raw material for this industry was estimated at $153,000,000$ lbs. (Messrs. Helmuth, Schwartze and Co's. Annual Report on wool, 1892), and the net imported supply (including yarn), after the re-exports have been deducted, 329,644,000 lbs., or 68.5 per cent. of the whole production. The number of persons occupied in industries connected with wool and 
directly dependent on wool number 301,249 , and the proportion to whom the foreign raw material gives employment is 206,356 .

\section{Cotton.}

This industry is entirely dependent upon imported foreign raw material, which (including yarn, but excluding re-exports) amounted in 1892 to $13,851,000 \mathrm{cwts}$. 670, 191 persons obtain, in one shape or anotber, employment from this industry, and the whole of them are entirely dependent upon sea-borne cotton.

\section{Flax (including Tow, Linen, and Yarn).}

The imported raw material, including yarn, for this industry was 1,915,000 cwts.; the home produce only 194,000 cwts., or only 9.2 per cent. of the whole amount consumed. The industry employs 1 22,992 persons, of whom I I 3,029 are dependent for their livelihood on foreign material. Home produced flax shows a rapid fall in 1891 and 1892.

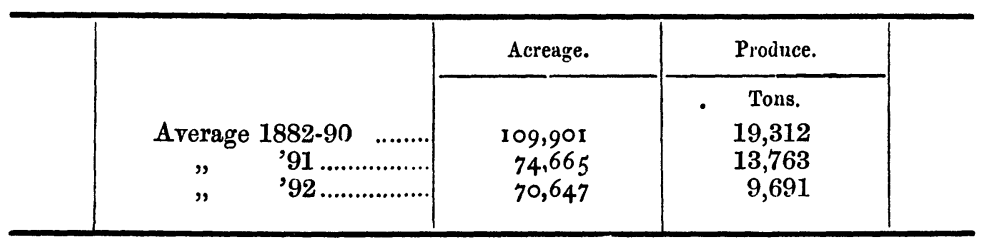

Gutta Percha and Caoutchouc.

This small but most essential industry employs 25,557 persons, the whole of the raw material used coming from abroad. The whole of the employés of the trade are dependent upon foreign material for their employment. Many other industries would be affected by a failure in the supply of gutta percha, notably machine makers and electricians, and a collapse in this industry would cause a disturbance among other trades out of all proportion to the numbers it employs or the dimensions of its own particular business.

\section{Hides and Leather.}

In this industry the import of raw material in the shape of hides, which are converted into leather here, and the import of manufactured leather must be taken together, for they form in the aggregate the source of supply to the whole leather and boot trade of the country. It has been difficult to obtain statistics as to the home production of hides, but eminent members of the trade state that the home production is much less than the amount imported from abroad. Assuming, which seems a fair estimate, that home produced hides constitute one-third of the total amount converted 
in this country into leather, two-thirds of the raw material here made into leather comes from abroad. The manufacture of home made leather is estimated to be about equal to and slightly in excess of the amount imported from abroad; it follows therefore that five-sixths of the leather used in this country comes either in the shape of raw material or manufactured leather from abroad. The number of persons engaged in this industry is 364,755 , of whom 83 per cent., or 302,746 are dependent for their daily wages upon imported supplies of hides and leather.

The centres of the boot trade are in the midland counties, remote from the sea, and at first sight little affected by maritime questions. Yet there is hardly an industry, excepting cotton, the members of which would be so injured by a stoppage of our great sea trade routes, as the boot and shoe trade in the centre of England.

\section{Wood and Timber.}

The total consumption of wood and timber in 1892 is estimated at $535,000,000$ cubic feet, of which $395,000,000$ cubic feet were imported from abroad, or 75 per cent. of the whole. The number of persons engaged in trades and industries is estimated at 395,386 , of whom 296,569 are dependent upon foreign imports.

\section{Bristle Trade and Brush Making.}

The bristles used for making brushes to a very large extent come from abroad. In this small but most necessary industry 17,702 are employed. It is difficult to accurately estimate how many are dependent upon foreign imports for the raw material they work up, but according to the best information I have been able to obtain, at least 80 per cent. of this number would be thrown out of employ by a stoppage of our imports.

I selected this industry as I considered it a typical one. There are many similar trades, where products are accepted as an automatic supply to the wants of a civilized community, but how the raw material is obtained which alone maintains the trade few care to investigate.

\section{Silk.}

The whole of the raw material employed in this industry comes from abroad. It employs 55,888 persons, all of whom are dependent for the wages on foreign supplies.

\section{Hemp and Jute.}

This trade is in the same category, and it employs 60,539 persons, who are in a similarly dependent position. 
Summary of Results arrived at.

Summarising the results thus obtained in the subjoined table, we find in Col. 4, the total number of persons employed and dependent on these selected trades, and they amount to 2,952,707. Col. 5 shows that of this number no less than $1,980,068$ are dependent for their livelihood upon open sea highways.

TABLE A.-Loss of Employment by Stoppage of Import of Raw Material alone (United Kingdom).

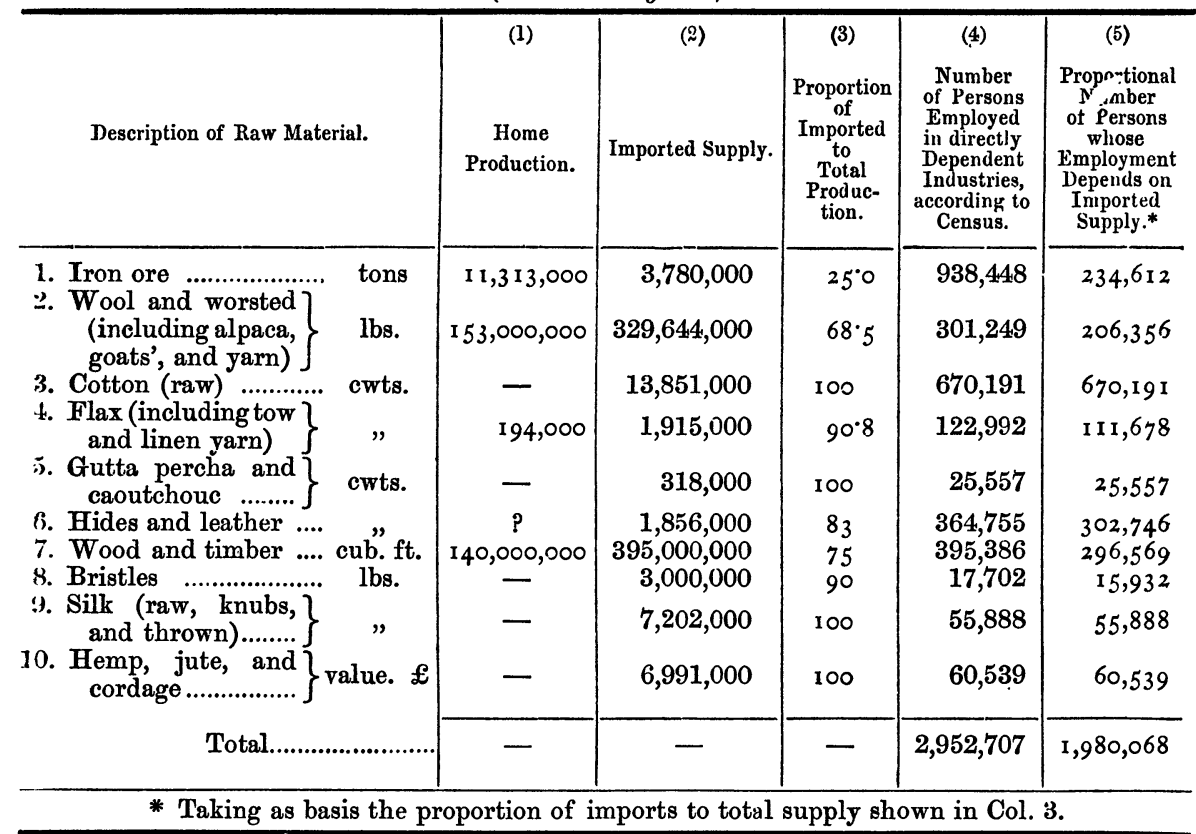

Census (1891) Figures of Numbers Engaged in different Industries.

\begin{tabular}{|c|c|c|c|c|}
\hline Class of Occupation. & $\begin{array}{c}\text { Enyland } \\
\text { and Wales. }\end{array}$ & Scotland. & Ireland. & $\begin{array}{c}\text { United } \\
\text { Kingdom. }\end{array}$ \\
\hline 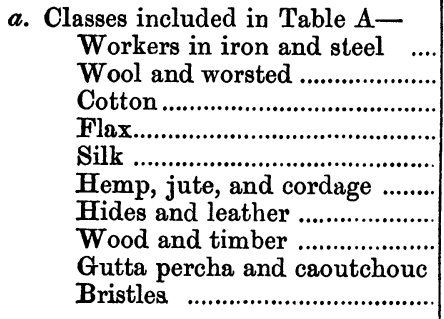 & $\begin{array}{r}776,731 \\
254,585 \\
629,184 \\
8,166 \\
51,4,27 \\
22,416 \\
311,961 \\
309,729 \\
22,136 \\
15,852\end{array}$ & $\begin{array}{r}132,661 \\
40,034 \\
36,728 \\
26,223 \\
4,132 \\
36,297 \\
27,393 \\
54,518 \\
3,314 \\
1,144\end{array}$ & $\begin{array}{r}29,056 \\
6,630 \\
4,279 \\
88,603 \\
329 \\
1,826 \\
25,401 \\
31,139 \\
107 \\
706\end{array}$ & $\begin{array}{r}938,448 \\
301,249 \\
670,191 \\
122,992 \\
55,888 \\
60,539 \\
364,755 \\
395,386 \\
25,557 \\
17,702\end{array}$ \\
\hline Tots & $2,402,187$ & 362,444 & 188,076 & $2,952,707$ \\
\hline
\end{tabular}


Now if one-third of the supplies coming from abroad were stopped no less than 660,000 persons would be without wages; or if the whole of those now engaged in those industries were employed on short time, they would have their present time reduced by one-third.

But this, so far from exhausting the reduction of wages in these industries caused by a block in ous sea routes, only touches the first of the trades upon which many other industries and occupations are almost entirely dependent. I have in the subsequent return included some few of the dependent industries and the numbers they employ. This list only notices a few of the larger subsidiary or dependent occupations, and is far from exhaustive, still it mounts up to the great figure of $1,330,000$ persons.

\begin{tabular}{|c|c|c|c|c|}
\hline Class of Occupation. & $\begin{array}{l}\text { England } \\
\text { and Wales. }\end{array}$ & Scotlind. & Ireland. & $\begin{array}{c}\text { United } \\
\text { Kingdom. }\end{array}$ \\
\hline \multicolumn{5}{|l|}{$\begin{array}{l}\text { b. Other large occupations seriously } \\
\text { affected, but not included in } \\
\text { Table A- }\end{array}$} \\
\hline $\begin{array}{l}\text { Cabinet makers, upholsterers, } \\
\text { \&c. }(11,2,1)^{*}\end{array}$ & 91,361 & 11,930 & 2,322 & 105,613 \\
\hline $\left.\begin{array}{r}\text { Mixed or unspecified textiles } \\
(17,5) \ldots \ldots \ldots\end{array}\right\}$ & 162,811 & 63,136 & 28,217 & 254,164 \\
\hline Tailor $(18,1,3)$ & 208,720 & 27,320 & 17,950 & 253,990 \\
\hline Milliner, dressmaker $(18,1,4)$ & 420,431 & $56,2,27$ & 46,787 & $5=3,445$ \\
\hline Shirt maker $(18,1,6)$ & 55,096 & 7,020 & 64,214 & 126,330 \\
\hline $\left.\begin{array}{c}\text { Hosiery manufacturer and } \\
\text { hosier }(18,1,7 \text { and } 8) \ldots . .\end{array}\right\}$ & 61,568 & 3,863 & 759 & 66,190 \\
\hline Total..... & 999,987 & I úg,496 & 160,249 & $1,3=9,732$ \\
\hline
\end{tabular}

* See note * on p. 127.

But in addition there are those employed in the work of transporting and distributing the products of manufacture and industry. It is difficult on this point to give anything like a complete estimate of those thus employed, but $\mathrm{Mr}$. Goschen, as Chancellor of the Exchequer, in speaking on the budget 11th April, 1892, alluded to the dimensions of the work of distribution as shown by income tax returns under Schedule D, as compared with production. "It is easy to leave out of account the immense "profits of the distribators of the manufactaring and productive " industries. If I take the total of these latter industries, includ" ing cotton, silk, wool, ready made clothing, metals, and hardware " of all kinds, ship building, refining, tanning, brewing, chemicals, "distilling, and so forth. If I take the whole of these industries "which cover so vast an area of our national prosperity, the "profits only amount to one-half of the profits which fall under "the head of distribution and transport. That is to say, that 
"those who distribute and transport merchandise and the "products of industry, make on the whole twice as much profit " as the producers and manufacturers of the articles."

Excluding those employed by railways and the great bulk of the small retailers, I find that the following classes would be affected by the disturbance I contemplate :-

Transport.

\begin{tabular}{|c|c|c|c|c|}
\hline Class of Occupation. & $\begin{array}{l}\text { England } \\
\text { and Wales. }\end{array}$ & Scotland. & Ireland. & $\begin{array}{l}\text { United } \\
\text { Kingdom. }\end{array}$ \\
\hline $\left.\begin{array}{l}\text { Carman, carrier, waggoner, \&c. } \\
(6,2,4)^{*}\end{array}\right\}$ & 170,256 & 26,527 & 7,386 & 204,169 \\
\hline Dock labourers $(6,3,4)$ & 54,996 & 6,789 & 4,322 & 66,107 \\
\hline $\left.\begin{array}{r}\text { Bargeman, lighterman, \&c. } \\
(6,3,2)\end{array}\right\}$ & 31,496 & 560 & 1,046 & 33,102 \\
\hline Merchant service $(6,3,3)$ & 107,834 & 18,085 & 9,809 & I 35,728 \\
\hline T'otal ............................. & 364,582 & $5 \mathrm{I}, 96 \mathrm{I}$ & 22,563 & 439,106 \\
\hline
\end{tabular}

The census of 1891 gives the grand total of the industrial and commercial classes throughout Great Britain and Ireland as numbering 10,689,000, yet this perfunctory examination I have made of some of the great trades, gives the appalling total of $4,721,545$ persons in the first instance whose employment in connection with these ten trades is directly or indirectly affected by stoppage of raw materials on the high sea. Besides these there are the women and children (not engaged in any occupation) dependent on those employed in these trades. Let this stoppage of work be associated with a sudden rise in the prices of necessaries, and the elements are complete for wholesale calamity and disaster.

\section{Comparison between 1881 and 1891.}

Let us now compare the imports of raw material for these same industries in 1881 and 1891, and the numbers engaged in each, and see to what extent our relative dependence on foreign material has in that interval increased, as shown by the tables below :- 
Imports of Raw Materials into United Kingdom in 1882 and 1892, and Numbers Employed in Industries Dependent on these Materials in 1881 and 1891.

\begin{tabular}{|c|c|c|c|c|}
\hline Description of Raw Materials. & Imports, 1882. & Imports, 1892. & $\begin{array}{c}\text { Number } \\
\text { Enployed, } \\
\text { 1881. }\end{array}$ & $\begin{array}{l}\text { Number } \\
\text { Employed, } \\
\text { 1891. }\end{array}$ \\
\hline 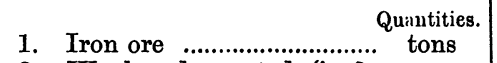 & $3,284,946$ & $3,780,5 \circ 3$ & $758,049 *$ & 938,448 \\
\hline $\left.\begin{array}{l}\text { Wool and worsted (in- } \\
\text { cluding alpaca, goats', } \\
\text { and yarn) ............................. }\end{array}\right\}$ & 517 , & 778,1 & 276,612 & 301,249 \\
\hline 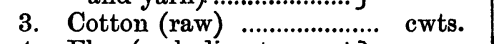 & $15,794,566$ & $15,850,324$ & 632,581 & 670,191 \\
\hline $\left.\begin{array}{l}\text { 4. Flax (ncluding tow and } \\
\text { linen yarn) }\end{array}\right\}$ & $2,010,765$ & $\mathrm{I}, 9$ 1 5,664 & 119,951 & 122,992 \\
\hline $\left.\begin{array}{l}\text { 5. Gutta percha and caout- } \\
\text { chouc.................................. }\end{array}\right\}$ & 254,662 & $3 \times 7,660$ & 8,588 & 25,557 \\
\hline 6. $\{$ Hides, raw, dry, and wet.... & $1,190,66.7$ & 77 & 11,373 & $\mathrm{I} 1,431$ \\
\hline 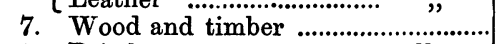 & $6,320,863$ & $\begin{array}{r}907,738 \\
7,696,000\end{array}$ & 396,475, & $\begin{array}{l}353,324 \\
395,386\end{array}$ \\
\hline 8. Bristles............................... lbs. & $2,563,075$ & $3,001,385$ & 17,472 & 17,702 \\
\hline $\left.\begin{array}{l}\text { 9. Silk (knubs and waste, } \\
\text { raw and thrown) ......... }\end{array}\right\}$ & 350 & $7,201,964$ & 67,359 & 55,888 \\
\hline 10. Hemp, jute, and cordage value. $£$ & $7,130,101$ & $6,991,231$ & 46,490 & 60,539 \\
\hline Total... & - & 一 & 94 & $2,95^{2,707}$ \\
\hline
\end{tabular}

* Shipwrights (iron) not included. † Shipwrights (wood) not included.

On perusal of this table it will be seen that, though in the aggregate the amounts imported in 1891 are considerably above those of 1881, yet the ratio of increase is small compared to that of food for the same period. The raw materials connected with the iron, wool, and wood trades show considerable rises; in the minor industries the amounts of bristles and gutta percha imported have considerably increased, but the leather trade is almost stationary ; so is cotton, whilst flax, hemp, jute, have gone back. On the other hand, the number employed in every industry has risen, except silk and wood.

A perusal of these figures seems to show that the increase of population, viz., $8 \cdot 2$ per cent., during the last decade, has been accompanied, so far as the industries here mentioned are concerned, with a corresponding development of employment, and it is clear therefore that if these industries are to grow and give more employment, their ratio of dependence upon sea supplies must steadily get greater.

It is impossible to leave the figures relating to imported food and imported raw material without a sense of apprehension and disquietude at the tremendous magnitude of the stake this country has in keeping free and open the trade routes of the sea. Heavy and unpleasant as may be the stake now, it must in the future 
grow greater and greater. We are in the position of a man forced to gamble, and to continually increase his stakes, not because he likes gambling, but because he cannot stop without starvation and rain.

It is a curious irony of events that the least excitable and most practical of the nations of the world should be forced into this huge and ever growing speculative risk, but we have now no alternative but to go on with what has been forced on us, but at the same time to minimise by prescient and never relaxing precautions the peril which must ever surround us.

\section{Transfer of Flag.}

It may be noticed that, in making these estimates of the contraction of our sea carrying power in certain eventualities, I have ignored and not taken into consideration the relief which many believe may be given by transfer of ships from our flag to that of some neutral power. It is maintained in certain quarters that this transfer will assume very large dimensions, and so doubtless it might if such a transaction in itself would give to a British shipowner and a British ship certain immunity and protection against the risks and molestation of war. But we have had a long and unvarying practical experience on this point. From 1698 to 1815 this country was six times engaged in serious war; in fact, during the greater part of that period it was at war, and the war, in almost every case, was fought out as much on sea as on land.

The following are the dates and duration of each of these six wars :-

1702 to 1712
'18, '21
'39, 44

1756 to 1762
'75, 83
'94, 1815

and the result of this long and painful experience has been to make clear beyond controversy that a neutral flag is not in itself sufficient prciection to neutral merchant vessels trading to the ports of a belligerent, unless the neutral has behind it a navy strong enough to ensure respect for that flag.

It would be altogether outside the scope of this paper and of the regulations of the Society for me to now attempt to argue this question at length, or even by my statements to provoke any discussion upon it, but I must briefly give my reasons for believing that for the subjects of the greatest naval power in the world to solicit the protection of a neutral flag to give to their property immunity from the risk and molestation from war, is too empirical a safeguard to set on one side facts and statistics based on experience. Wars break out suddenly, and sometimes without premonitory 
symptoms, and the early stages of a naval war are the most dangerous to a widespread commerce, for it is before the defence is adapted to the new condition of things that most risk would arise and rates of insurance be highest. It is a curious, but at the same time a significant fact that the countries to whose flag transfers can be easiest made, and whose laws impose fewest formalities to such a transfer, are those whose navies are least powerful. Moreover it is a statistical fact that all the neutral powers in the world, if they combined together, could not man half the British mercantile marine, unless they laid up their own merchant vessels.

But above these considerations arises a much more difficult and undefinable question. What articles are or are not contraband of war? Is food? A great naval power in conflict with a weak naval power only nine years ago did so declare itself, "on the ground " that by the side of those articles included from their very nature " under contraband of war, such as arms and munitions, the are " others the trade in which may be incidentally prohibited in " time of war, by reason of their usefulness to the belligerents." (Circular of French Government, 21st February, 1885.)

Those who wish to get a side light from a strong and impartial authority upon this subject, should read an article, written by Mr. T. Russell Solby, Assistant-Secretary to the United States Navy, in "Scribner's Magazine" (November, 1889), and I think they will all concur in believing that what hereafter under a neutral flag will be treated as contraband of war, almost entirely depends upon the respective powers of the belligerents themselves.

I only refer to these matters not to provoke reply or argument on this point, but merely to justify myself in refusing to allow the idea of transfer from one flag to another to invalidate the statistical conclusion I am endeavouring to establish.

\section{Conclusion.}

Before I conclude this paper, I wish to explain that, in calling the attention of this Society to the increasing dependency of this country upon its foreign trade for its food supply and the maintenance of its industries, I neither wish to find fault with what has been done in the past or to advocate the reversal of that policy in the future. My object in asking you to statistically discuss and examine our present position is to utilize the great authority and influence this Society has with the general public, in order that, with increased wealth and improved food supplies, we may combine a full knowledge of the sources from which we obtain these benefits and of the means by which, in emergencies, the sea routes through which they come may be kept open and free. 
Risk is coincident with life, and no nation, be it island or insular, has not always attached to it some kind of danger and drawback. The sword that hung over the head of Damocles was dangerous because it was only held up by a single hair; if it had been restrained by a good substantial chain, posterity would have heard very little of his ever present anxiety. I want this Society to first examine from their own standpoint, viz., that of statistics, whether there is or is not such a sword hanging over our food supplies and our industries, and if they arrive at the conclusion that some such peril can be proved by the stern and inexorable figures of economic science, then to utilise their statistical knowledge to show how such a danger can be reduced and safeguarded.

The prosperity and well being of a great nation are like the business and property of a great corporation or firm; they must be insured against certain risk, and the premium which is annually paid against that risk must be regulated largely by the value of the property to be protected, and as that property grows in value and bulk so must the premium be increased.

I only ask you as statisticians to look in the same light on the problem I have ventured to discuss, and to remember that the annual insurance which we should pay to keep open the ocean highways, must not merely be regulated by the value of the commerce or merchant fleet that comes by those routes, but by the knowledge that the freedom of sea communications between Great Britain and the outer world is as essential to her existence as the passage of air through the windpipe of any human being is to the preservation of his life.

Before I sit down, I should like to express my thanks for the great assistance that I have received from the Honorary Secretaries, Assistant-Secretary, and Chief Clerk of the Society in the preparation and compilation of the figures contained in this paper. 
1894.] on the Food and Wages of Great Britain.

\section{APPENDIX.}

Details of Occupations of Persons Dependent on Supply of Raw Material.

\begin{tabular}{|c|c|c|c|c|c|c|c|c|}
\hline \multirow{2}{*}{ Occupations. } & \multicolumn{2}{|c|}{ England and Wales. } & \multicolumn{2}{|c|}{ Scotland. } & \multicolumn{2}{|c|}{ Ireland. } & \multicolumn{2}{|c|}{ United Kingdom. } \\
\hline & 1881. & 1891. & 1881. & 1891. & 1881. & 1891. & 1881. & 1891. \\
\hline $\begin{array}{l}\text { 1. Iron Ore- } \\
\text { Workers in iron and steel }\left(21,8^{*}\right) \ldots \ldots . . \\
\text { Shipwrights, iron }(13,1, \text { part }) \ldots \ldots \ldots \ldots . . . \\
\text { Machines and implements }(10, \text { all }) . . . .\end{array}$ & $\begin{array}{c}361,343 \\
-\dagger \\
267,976\end{array}$ & $\begin{array}{r}380,193 \\
54,307 \\
342,231 \\
\end{array}$ & $\begin{array}{l}62,594 \\
\underset{38,600}{+}\end{array}$ & $\begin{array}{l}68,040 \\
13,195 \\
51,426\end{array}$ & $\underset{6,458}{21,078}$ & 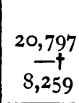 & $\begin{array}{l}445,015 \\
-t \\
313,034\end{array}$ & $\begin{array}{r}469,030 \\
67,502 \\
401,916\end{array}$ \\
\hline Iron Ore-Total ... & 629,319 & 776,731 & 101,194 & $132,66 \mathrm{I}$ & 27,536 & 29,056 & 758,049 & 938,448 \\
\hline 2. Wool and Worsted $(17,1) \ldots \ldots \ldots \ldots \ldots . . . . . . . .$. & 233,256 & 254,585 & 35,646 & 40,034 & 7,710 & 6,630 & 276,612 & 301,249 \\
\hline 3. Rıw Cotton $(17,3$, excluding flax $) \ldots .$. & 574,405 & 629,184 & 51,332 & 36,728 & 6,844 & 4,279 & 632,581 & 670,191 \\
\hline 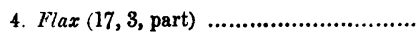 & 12,065 & 8,166 & 28,733 & 26,223 & 79,153 & 88,603 & 119,951 & 122,992 \\
\hline $\begin{array}{l}\text { 5. Gutta Percha and Caoutchouc- } \\
\text { Bicycle maker }(12,1, \text { part }) \ldots \ldots \ldots . . . . . . \\
\text { India-rubber worker }(20,1, \text { part }) \ldots \ldots\end{array}$ & $\begin{array}{l}1,072 \\
6,548 \\
\end{array}$ & $\begin{array}{l}11,524 \\
10,612 \\
\end{array}$ & $\begin{array}{r}13 \\
924 \\
\end{array}$ & $\begin{array}{r}142 \\
3,172 \\
\end{array}$ & $\begin{array}{r}1 \\
30\end{array}$ & $\begin{array}{l}62 \\
45 \\
\end{array}$ & $\begin{array}{l}1,086 \\
7,502 \\
\end{array}$ & $\begin{array}{l}11,728 \\
13,829 \\
\end{array}$ \\
\hline Gutta Percha and Caoutchouc--Total...... & 7,620 & 22,136 & 937 & $3,3 \sqrt{14}$ & 31 & 107 & $8,5 \varepsilon 8$ & 25,557 \\
\hline $\begin{array}{l}\text { 6. (a.) IIides- } \\
\text { Tanners, fellmongers }(19,2 \text {, part) }\end{array}$ & 10,248 & 10,348 & 816 & 8 & 309 & 265 & 11,373 & II,+3 I \\
\hline $\begin{array}{l}\text { (b.) Leather- } \\
\text { Saddler, harness maker }(12,2) \ldots \ldots \\
\text { Shoemaker, \&c. }(18,1, \text { part })\end{array}$ & $\begin{array}{r}23,866 \\
216,556\end{array}$ & $\begin{array}{r}27,321 \\
248,789\end{array}$ & $\begin{array}{r}2,150 \\
24,371\end{array}$ & $\begin{array}{r}2,382 \\
21,749\end{array}$ & $\begin{array}{r}2,812 \\
26,791\end{array}$ & $\begin{array}{r}2,883 \\
21,506\end{array}$ & $\begin{array}{r}28,828 \\
267,718\end{array}$ & $\begin{array}{r}32,586 \\
292,044\end{array}$ \\
\hline 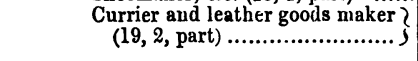 & 20,891 & 25,503 & 2,287 & 2,444 & 751 & 747 & 23,929 & 28,694 \\
\hline Leather-Total ...... & 261,313 & 一 & 28,808 & - & 30,354 & - & 320,475 & 353,324 \\
\hline $\begin{array}{l}\text { 7. Wood and Timber- } \\
\text { Workers in wood and bark }(20,3) \ldots \ldots \\
\text { Carpenters and joiners }(11,1, \text { part) } \ldots . \\
\text { Wood carrers }(11,3, \text { part) } \ldots \ldots \ldots \ldots . . . \\
\text { Shipwrights, wood }(13,1, \text { part) .......... }\end{array}$ & $\begin{array}{r}75,338 \\
235,233 \\
3,108 \\
-\dagger \\
\end{array}$ & $\begin{array}{r}76,755 \\
221, \infty 09 \\
3,555 \\
8,410 \\
\end{array}$ & $\begin{array}{c}13,460 \\
35,352 \\
504 \\
-t \\
\end{array}$ & $\begin{array}{r}14,528 \\
31,402 \\
702 \\
7,886 \\
\end{array}$ & $\begin{array}{r}7,972 \\
25,373 \\
204 \\
-+ \\
\end{array}$ & $\begin{array}{r}7,315 \\
23,668 \\
156 \\
-t \\
\end{array}$ & $\begin{array}{r}96,770 \\
295,958 \\
3,816 \\
-\dagger \\
\end{array}$ & $\begin{array}{r}98,598 \\
276,079 \\
4,413 \\
16,296 \\
\end{array}$ \\
\hline Wood and Timber-Total............ & 313,679 & 309,729 & 49,316 & 54,518 & 33,459 & 31,139 & 396,544 & 395,386 \\
\hline $\left.\begin{array}{l}\text { 8. Bristles- } \\
\text { Hair, bristle worker, and brush, } \\
\text { broon maker }(19,3 \text {, part)................ }\end{array}\right\}$ & 15,355 & 15,852 & 954 & $\mathrm{I}, \mathrm{I} 44$ & 983 & 706 & 17,472 & 17,702 \\
\hline 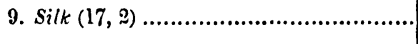 & 63,577 & 51,$42 ;$ & 3,163 & 4,132 & 619 & 329 & 67,359 & 55,888 \\
\hline 10. Hemp, Jute, and Cordage $(17,4)$ & 22,471 & 22,416 & 22,056 & 36,297 & 1,963 & I,826 & 46,490 & 60,539 \\
\hline
\end{tabular}

* These figures refer to the Order and Sub-Order in the Classification of the Occupations in the Census returns, 1881 and 1891 .

+ Shipwrights in irou and wood not distinguished. The comparison of all shipwrights is as follows:-

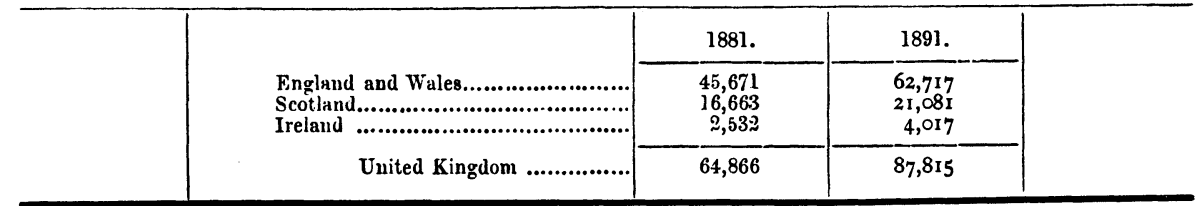




\section{Discussion on Lord George Hamilton's Paper.}

The President said that whereas statistics had often been placed before the Society showing the increasing prosperity of the country, this paper pointed out the dangers attending that prosperity. His personal position was that of a shipowner, and he had been much struck with what Lord George Hamilton had said concerning the neutral flag. Probably he was right in the view he had taken of the impossibility of transferring our merchant vessels to a neutral flag, but even if it were practicable, it was at best a disheartening way of keeping our trade. Was it not possible to find some other method than the old one of convoys, by which our merchant ships might be protected in time of war? Could not the steamerssailing and acting together-to some extent protect themselves by exercising those latent powers of collision which they all possessed? The actual losses which privateers or cruisers could inflict upon us would not be so serious in themselres as the demoralisation arising from the fear of them. We could perfectly well afford those losses if they were borne jointly, and it was while we were still at peace that this question must be carefully considered. He felt sure that shipowners would be patriotic enough to be ready to meet the authorities in attempting to make some such arrangement, and if it were made, it would stimulate the efforts of the crews as well as of the owners in maintaining our trade.

Sir JoHn C. R. Cогомв emphasised the paramount national importance of this question, and its ever growing proportions. Lord George Hamilton had confined his inquiry to Great Britain, but the student would not be able to follow it up without some reference to the dependencies of the United Kingdom. There was one governing consideration which had an important bearing on this matter, and that was the automatic suspension of foreign business preceding all warlike operations. If, for instance, France or Russia were to declare war against us, the whole of our trade with those two countries would be immediately stopped. Any calculations as to the percentage of probable reduction in our trade due to actualities of war operations must therefore be made on the reduced tonnage, i.e., after deducting from the whole tonnage that part of it which was employed in the French or Russian trade. He agreed that the sailing ships would all be immediately laid up, and he could cite an example from the American civil war. When it was known in the eastern hemisphere that the "Alabama" was cruising between the West Indies and the Cape, seventeen American clippers, aggregating over 12,000 tons, were at once laid up in one port alone (Singapore). He did not think it possible to draw a line between fast and slow steamers, a good deal depended, amongst other things, on the coal-carrying capacity of the 'indi- 
vidual steamer, enabling her to make détours out of the beaten track. The automatic suspension of trade was very important, and would be found to vary with the quarter from which the war came. For instance, a war with France would not throw any ocean steamers automatically out of employ, but a war with America would. There would be no automatic reduction of our trade with our own empire, and we did more trade with our own empire than with any foreign country, and each part of the Empire did more trade with England than with any foreign country. An interesting case of the automatic effect of a war on food supply would be found in a paper in the Society's Journal for 1863. Another important consideration was that. apart from the growth of our dependence on foreign imports, the geographical distribution of the sources of our supply had changed during the last twenty years. Our supply came now from much further afield, and consequently required protection over greater distances. While in 187153 per cent. of the 26,000,000l. worth of wheat and flour imported came from Europe and the Mediterranean ports, the proportion had fallen in 1891 to only 24 per cent. on a value of $31,000,000 l$; the remaining 76 per cent. being brought from Asia, America, and Australasia.

Another very important element which exercised its influence on the whole social condition of the country, was the margin of profit. Manufactories would be shut up and employment cease if there were no profit and no prospect of profit. Whetber coincident or not with our increased dependence on the sea, it was very generally conceded that the margin of profit had shrunk between 1871 and 1891. The effect of any interference with our lines of supply would increase the cost of raw material, the freights, and the insurance, and this extra cost must fall first of all on the margin of profit. The extinction of this margin, combined with a rise in the price of bread, would have a very far reaching effect. Inefficient means of defence for our ocean communications in time of war meant a simultaneous and universal closing of factories in Great Britain, an unemployed population in our streets, and dear bread in our shops. They had once before had a terrible practical lesson at Manchester what the restricted import of the single article of cotton meant. Professor Leone Levi in 1863 estimated that at that time " 400,000 persons were thrown out of employment and forced to depend upon the charity of their fellowmen for their sustenance."

Lord George Hamilton had not considered the exports of coal. These amounted in 1851 to $3,500,000$ tons, and in 1891 to over $30,000,000$, and this proved the growing dependence of the coal miners (numbering 650,000) on delivery by sea. The distress and disastrous effects caused by the recent strike of coal miners were as nothing in comparison with what would follow a serious interruption of our ocean communications.

With regard to the transfer of our flag, he would point out that to depend on a neutral flag to carry on our commerce during war, was to depend on our being able to get rid of our shipping at a moment's notice. Suppose that at the end of an unsuccessful war

VOL. LVII. PART I. 
we were called upon to hand over our mercantile marine to a victorious enemy, who would then doubt that Britain's sun had set? But a voluntary transfer would simply be commencing the war by levying this gigantic requisition on ourselves in the form of a forced sale, for no belligerent would recognise a fictitious transfer. It would be giving away our merchant fleet with a pound of tea.

Sir RAwson W. Rawson said that the importance of this paper could not be over-estimated, and that immediate action should be taken with regard to the facts now brought clearly before the public. It was by no means necessary that the extreme mischief mentioned by Lord George Hamilton as possible should operate : a partial stoppage of our sea-borne trade would be quite sufficient to cause incalculable damage. In support of this view he could quote the instance mentioned by Sir John Colomb. The price of cotton just before the American civil war was $3 l$. per cwt., two years later it was izl. per cwt.; and the immense damage to our cotton industry during that period had been caused, not by an enemy at our doors, but by a civil war 3,000 miles away, producing only a partial stoppage of the supply of our raw material in that one branch of our national industry. Food and raw materials formed fire-sixths of all our imports. It was not necessary to go the length of the author, and assume that one-third of our imports would be stopped. If war risks, war freights, and war insurance, were added to the cost of our food and raw materials, they would be quite sufficient to bring universal calamity on the empire.

Had we been an island in the midst of the ocean, all our coasts would have been open, and no hostile fleet would have been able to shut up all our ports; but as a matter of fact, only the least important part of the country was open to the ocean: the most importint lay in such a position that an enemy gaining the command of the seas could at once close the main entrances for our commerse. There were practically only three channels of communication with this country: 90 per cent. of the whole imports of the United Kingdom come to England and Wales, and more than 60 per cent. of this trade was concentrated in three ports of Loudon, Liverpool, and Hull (with Goole and Grimsby). ${ }^{1}$ These figures showed the extent to which our trade was concentrated along a few lines of communication. Considering the question of insurance, the profits on an annual trade of $700,000,000 \mathrm{l}$. of imports and exports ought to be at least ro per cent., i.e., the annual profits were at least $70,000,000 \mathrm{l}$. He thought that no one in private business would hesitate to pay 10 per cent. or $7,000,000 l$. per annum to secure such a profit. The question should be viewed in that light. We ought not to begrudge what was absolutely necessary to maintain our trade. We ought to be in a position strong enough not only to prevent any hostile power or combination of powers from interfering with our trade, but to deter any from making the attempt.

1 See the next article, p. 136. 
Mr. JoHn Glover said that naval defence, as related to the question of work, wages, and food, directly concerned the great mass of the people. The purpose of the paper was to convince those who had not thought about the matter at all, that this was a question which came home directly to every man who laboured, who depended for living on his weekly wages, and to all who desired for the people an uninterrupted and abundant supply of cheap food. Lord George Hamiltou made a clear statement of the facts, so that the public might not cherish the illusion that now, at the end of the nineteenth century, we could live as our fathers had lived fifty years ago. We had in fact lived into a completely new set of economic conditions. Fifty years ago the population of the United Kingdom was 26,000,000, now it was approaching 39,000,000. Fifty years ago we grew 14,000,000 quarters of wheat, and did not consume much more; last year we grew 7,000,000 quarters, and were going to eat $28,000,000$. We cannot therefore live, and ought not to legislate as if we were living in the ancient conditions. All our policy must be adjusted to the new and inexorable conditions of our changed circumstances. No other nation is dependent on free maritime communications as we are, and therefore we must adopt a policy of our own, and not bo influenced by what happens to suit other countries otherwise circumstanced. We depend for three-fourths of our bread on foreign nations and open sea communications, whereas most other countries could feed themselves. Being absolutely dependent on sea communications, our maritime supremacy must be maintained, in order to secure which the naval question in England should be made the first of all questions. It concerned all Englishmen alike, and belonged to no particular party; and it ought to be above all party questions.

He would like to emphasise what had been said concerning the transfer of our ships to other flags in order to carry on our enormous transport business. Speaking as a shipowner, he considered it a delusion. There were very few countries under whose flag neutrality wonld be worth anything, and those countries had not the money with which to buy our ships-we should have to give them away. There was another serious objection to this course. During the American civil war the northern States sold their ships to Europe; we had bought a great many of them, and the carrying so lost by the United States had never been recovered. They had lost the bulk of their own sea carrging trade. It was a matter of common knowledge, and could easily be proved statistically, that from being formidable competitors of the United Kingdom, the United States had, since 1863, lost their place as over-sea maritime carriers. That would not suit Englishmen. He hoped the Government would make some arrangement while we were still at peace, so as to guarantee to British shipowners the practical neutrality of its flag, and take on itself the risk of capture under all circumstances. He cherished one more hope. It had been apparent in all recent wars that maritime captures had exceedingly little influence either on the duration of wars or on the fortunes of the combatants; he hoped that the Governments of 
Europe would ere long give the European peoples the assurance that even Goveruments are becoming more rational and more humane, by coming to an agreement amongst themselves to respect private property at sea as much as on land, and so limit and circumscribe the calamities of war when they could not be avoided. It would be accordant with all the better teachings of our civilisation to effect this change in international law, and most honourable to the Governments by whose example the change was initiated.

Mr. H. O. ArNold-Forster, M.P., said that if the full value of this paper were to be known, the lessons it taught ought to go far beyond the room in which they then were. It was sometimes said that the great towns outside London did not take an interest in these matters, but that was not his experience at all. If the Society could tabulate and explain these details in such a form that they could be brought home to the large towns such as Manchester, Bradford, and Belfast, they would be adding very largely to the debt of gratitude the public already owed them for having brought this matter forward. The one great practical step which seemed to arise from the discussion was, he thought, the plan for marine insurance in the case of war. This was eminently a matter for the Society to take up, for there were at present no statistics on which even the outline of a complete system of marine insurance could be based. Mr. Glover had truly said that captures at sea had not been a determining factor in any war of the past, but the whole essence of the paper had been to show that they might be so in the future. We required to abolish the fear of capture, and that could only be done through marine insurance.

These matters had often been considered merely as hypotheses, but there was no doubt that there was a large school of thought abroad which did make the carrying out of such a policy a part of the established literature and ideas in various countries. Only the other day he had been reading the words, not of a pirate, but of an admiral and Minister of the French Republic, who had stated distinctly that he looked forward to seeing torpedo boats destroying the British mail steamers on the high seas under cover of night. The admiral had not considered that the crew of the torpedo boat were liable to be hanged for piracy, but that was the sort of literature with which he (Mr. Arnold-Forster) was familiar. The facts stated in the paper were not only possible, but probable.

There was a temptation in the case of foreigners beyond anything which could affect shipowners in this country. He had been told by a prominent shipowner that if he were to transfer his ships, under colour of a bill of sale, to the French Government, he would receive $200,000 l$. per annum, out of French taxes, for merely condescending to exist, without any subsidy for mails, \&c. If we were at war to-morrew, and took in one day every ship our greatest competitor, France, possessed, and every colony they had on the day after, the French nation would absolutely be richer on the third day. There was a dead loss on the French colonial 
budget, and the same applied to the shipping subsidies. Therefore the risk was all on one side, and the temptation on the other. $\mathrm{He}$ wished these facts to go out broadcast into the country, and he knew that their own inherent value and strength was conclusive and all-sufficient to enforce them in that meeting. But it must be remembered that these were not mere abstractions ; they were the possibilities and probabilities of everyday life.

Mr. Stephen Botrne wished to lay stress upon the insufficiency of a comparison of the increase of our trade when taken in terms of value instead of volume. The extreme depression last year had materially altered the condition of the figures subsequent to those which he (Mr. Bourne) had laid before the Society last spring, and he had now before him the figures for the last sixteen years. In that time the whole external trade of the country had only increased in money value by $38,000,000 l$., but that might be resolved into the difference between an increase in quantity equivalent to $260,000,000 l$., and a decrease in price of $222,000,000 l$. This manifestly showed the moderation of Lord George Hamilton's figures, and enhanced the importance of protecting this enormous trade. He would make one other remark to guard against the very prevalent custom of attaching more value to imports than to exports. He held that the exporting capacity of the country dominated its power of paying for its imports, and it was also the means by which we invested so much money in foreign countries and in our colonies. He was therefore inclined to attach more primary importance to our export than to our import trade. In the case of war with one country, it would be the interest of some countries to continue sending us the goods which we bought from them; but it was quite the contrary with respect to our exports, for all the countries of the world would unite to check the amount of goods we exported, in order to encourage their own manufactures, to which we were such extensive rivals.

Mr. W. J. HARRIS remembered that in 1868 Cobden had called attention in Parliament to the danger of an enemy's blockading our ports and starving us into submission. We had only a few ports into which the large vessels of which our mercantile marine was composed could enter, and if our fleet were beaten, there could be no doubt that all the estuaries leading to those ports would be blockaded. Ireland would be taken no account of by a hostile fleet so far as blockading was concerned. All their attention would be devoted to the ports of Great Britain. Count Caprivi, in a speech about eighteen months ago, had expressed the opinion that in the next outhreak of a war wheat would be declared contraband, and he (Mr. Harris) considered that we were running the greatest possible risk by growing the small acreage of wheat that we were growing. He fully agreed with the noble Lord in his advocacy of our having a strong fleet, but there was no doubt whatever that in case of an unsuccessful war, both exports and imports would be entirely cut off, and unless we took measures to grow far more 
wheat at home than we now did, and altered our fiscal system accordingly, we were running the greatest possible risk.

The President, intervening, said he thought the speaker was departing from the matter contained in the paper.

Mr. Harris said that he of course bowed to the President's ruling, but this very important matter had been alluded to in the paper, and he was glad to have had the opportunity of speaking.

Mr. A. E. Bateman said that reference had very properly been made to the only experience the present generation had had of a failure in the supply of a staple raw material. He could give some information as to what had occurred during the cotton famine of 1861-64. At that time our imports of raw cotton fell in a single year from 10,000,000 cwt. to less than 5,000,000 cwt.; the effect was that the number of out-door paupers in England and Wales rose from an average of three-quarters of a million to $1,000, \infty 00$, and 5 per cent. of the population were paupers. At the present moment, with the existing distress, we had only 600,000 out-door paupers, i.e., about 2 per cent. The situation was of course far worse in the cotton districts taken separately; pauperism rose there by more than 140 per cent., and more than $4,000,000$. were spent in simply providing the working classes with $2 s$. a week, with such clothing as was possible, and with a certain amount of lodging. All this distress arose from a failure in the raw material of only one industry, and was to a certain extent counterbalanced, because what the cotton industry lost was in part gained by the woollen and linen industries, which were exceedingly prosperous; but under the circumstances which Lord George Hamilton had so ably brought forward, all industries would alike suffer to a most deplorable extent. At the time of the cotton famine, as shown by Government Reports, bread in Lancashire was plentiful and cheap, yet there was every evidence of famine except pestilence and fever. It was now eighty years since we had had really dear food. The few figures he had given would serve to indicate what a fearfal situation would arise if, at the same time, the quartern loaf went up to $1 s$. 1od. (as in the Napoleonic wars), and the occupations of the people were taken away by the want of raw materials and of the power of exportation.

Lord George Hamilton, in reply, said that Mr. Glover had analysed succinctly his main object, which was to try and bring home to the minds of the general public that the conditions under which we were now living had changed, were changing, and must continue to change; and that until this was clearly understood, the public would not fully realise how inefficient in certain directions were the precautions adopted to prevent the occurrence of the calamities he had alluded to. He was glad to find that Mr. Bourne considered the facts laid before them as rather nnderestimated than over-estimated. There were two phrases to which people generally clung, one was the "transfer of flag," and the 
other the "command of the sea." People seemed to think that we could so retain command of the sea during a war, that vessels under the English flag would have the same immunity as in time of peace. But in no war which had lasted any considerable time, had we ever possessed such command of the sea as to be able to obtain immunity for all our vessels. In these days, it was quite clear to all concerned in the shipping trade that the increased risk and insurance would to a considerable extent dislecate our trade, and prevent those who now carried on their business with a certain profit, from being able to do so in a time of war.

His second object in reading this paper had been to induce others to follow up the subject. The question of marine insurance, as suggested by Mr. Arnold-Foster, would form a very legitimate subject for discussion. Mr. Glover had stated the value of our whole trade to be $700,000,000 l$., but that sum, vast as it was, did not represent anything like the full value of that trade to the country, for, from the moment it entered the country, it was turned over and over again in various occupations. If any statistician would take up one of the big trades-say the steel industryfollow it thrungh all its ramifications, note what became of all the ore inported, ascertain how far other trades were dependent on it, and what would be the effect upon other trades if they were deprived of the steel made from that ore, he would be amazed to find the enormous number of occupations dependent upon or connected with that industry, and how the stoppage of any considerable part of our import of ore would upset the trade of the country.

Sir Rawson Rawson had alluded to the fact that our position was not that of an island in mid ocean. One side of these islands was in close neighbourhood to Europe, where were the great navies which might molest our steamers. If we were involved in any great war, we should undoubtedly not be able to use the ports nearest the continent with the same freedom as now. He had spoken of vessels of over and under twelve knots speed; this figure did not represent any imaginary division between those ships which would be likely to be molested and those likely to escape. He had merely taken this figure because there were no estimates of the number and tonnage of vessels below that rate; and the small number above that rate showed what a large proportion there must be which could only develop a low speed. If it could be worked out, a very considerable proportion would, he believed, be found to be under eight knots, and all these would undoubtedly be laid up. In conclusion, he hoped that the results of this discussion would be not only to impress upon the public outside the permanent importance of the question, but to bring home to them the fact that it was a subject which bore, above all classes, upon the poorest class in the kingdom.

A cordial vote of thanks was then unanimously passed to Lord George Hamilton for his paper. 